\title{
THE PLACE OF RESEARCHERS \\ IN SOCIAL SECURITY POLICY MAKING
}

\author{
W. ANDREW ACHENBAUM \\ The University of Michigan
}

\begin{abstract}
Social Security policymakers are frequently characterized as "insiders" and "outsiders," depending on their proximity to Capitol Hill and Social Security Administration headquarters. Social Security researchers, in turn, are here described as "scholars" if they are primarily interested in investigating the system as a case study of some broader intellectual or disciplinary concern and as "technicians" if they concentrate on nuts-and-bolts issues that affect the system's operations, administration, and image. Only occasionally have social science scholars and technicians effectively collaborated in setting a policy relevant research agenda for Social Security. The author makes suggestions for fruitful avenues of future work.
\end{abstract}

"Contemporary social science," observed Robert Lynd (1939, p.1), "contains within itself two types of orientation that divide it into two blocks of workers: the scholars and the technicians." Both camps take for granted a certain complementariness in the common task of exploring the unknown. In actual practice, he contended, the two realms usually pull apart. The resulting mutual intellectual impoverishment diminishes either's ability to apply knowledge to improve social conditions or to enlighten citizens.

The gap between scholars and technicians, in Lynd's opinion, was a product of the way that knowledge was organized and utilized in the United States. Those based in colleges and universities pursued social science as an atomistic enterprise, wherein only the rigorous accretion of bits of knowledge would yield insight. Researchers had grouped themselves along departmental lines since the nineteenth century, and their academic specializations were still subdividing. Thus, as is the case today, scholars were more likely to grapple with the intellectual challenges and to pursue the academic rewards of their respective disciplines than they were to pay much attention to the administrative details and relevant political considerations that preoccupied the technicians (Oleson and Voss 1979; Haskell 1984). Conversely, social science researchers

Direct all correspondence to:W. Andrew Achenbaum, Institute of Gerontology, University of Michigan, Ann Arbor, Michigan 48109.

JOURNAL OF AGING STUDIES, Volume 2, Number 4, pages 301-309

Copyright $\odot 1988$ by JAI Press, Inc.

All rights of reproduction in any form reserved.

ISSN: 0890-4065. 
engaged in the practical affairs of monitoring institutional operations were predisposed by choice and by necessity to accept the statement of an intellectual issue as defined by the politics of the moment. Particularly in the wake of the Great Depression, organizational constraints, financial exigencies, and undeniable societal pressures put a greater premium on fast action and immediate results than on a thoughtful deliberation of salient questions pertaining to operational concepts and data analysis. As a consequence, Lynd declared, "important problems tend to fall into oblivion between the two groups of workers; and the strains generated by current institutional breakdowns are prompting sharp and peremptory scrutiny of the roles and adequacy of social sciences" (Lynd 1939).

Lynd's thesis has special pertinence in assessing the historical place of researchers in Social Security policy making. From the start, research has been a motor driving the development of what has evolved into the nation's largest domestic program. Only in rare instances, however, has there been a constructively critical dialog between scholars and technicians working in this area. On the academic side, differences in professional training and in the intellectual objectives of basic and applied research have limited chances for meaningful cross-disciplinary debate. On the policy side, the uses that politicans have made, and have chosen not to make, of the information generated through social science research have rarely been based on dispassionate scrutiny. Lawmakers derive policy options from a pragmatic political and economic calculus, mainly using data readily accessible and consistent with a position they endorse.

The fragmentation of Social Security research is hardly news, but acknowledging that reality raises questions for the sociology of knowledge. Is it possible to identify a common ground for conceptualizing Social Security issues that is pertinent both to scholars and technicians? Might a framework that explicitly demands the incorporation of multidisciplinary approaches to policy-relevant research enable us to bridge the interests of the two social science camps? I think so. The articles in this special issue suggest a manner of analysis and a mode of discourse that experts interested in aging studies might adopt in thinking and writing about the evolving nature and impact of Social Security. And they reaffirm efficacious patterns of knowledge-building that took shape in the 1930s.

\section{THE FIRST WAVE OF SOCIAL SECURITY RESEARCH}

At the very beginning, scholars and technicians joined forces in creating the omnibus piece of legislation. They hoped to provide a measure of "security against the major hazards and vicissitudes of life" that could meet the approval of Congress and the Supreme Court. Many of the key players either possessed expertise in social insurance matters or had experience in public administration. The five cabinet-level officers the president appointed to the Committee on Economic Security were predisposed to rely on social science research to develop policy initiatives. Later Secretary Frances Perkins and Federal Emergency Relief Administrator Harry Hopkins, for instance, had social work training and were successful at earlier stages of their careers in translating scholars' ideas into policy innovations. They in turn chose Arthur Altmeyer, who had served as Wisconsin's chief statistician and secretary of the state's industrial commission before becoming an assistant secretary of labor, to head a 21-member technical 
board that designed a research agenda. This body was flanked with expert advisory committees composed of actuaries, physicians, medical administrators, and public employment, public assistance, and child-welfare professionals. Edwin Witte, Chairman of the Economics Department at the University of Wisconsin, was appointed executive director of a full-time research staff to review the existing Social Security literature and to conduct whatever case studies were deemed appropriate.

Within a six-month period, Witte and a staff of more than eighty research assistants and consultants issued nine major reports on unemployment compensation, old-age security, child welfare, public employment and relief, employment opportunities, health in relation to economic security, and social insurance. In addition, they prepared scores of memoranda and position papers on topics ranging from constitutional questions and actuarial estimates of future costs, to analyses of foreign experiences of Social Security legislation, and a philosophical inquiry into the meaning of "social insurance" itself. On the basis of this outpouring and his own prior research, Witte drafted a 50-page report for the Committee on Economic Security to submit to Franklin Delano Roosevelt.

Accounts of the politicking and legislative particulars surrounding the enactment of the 1935 Social Security Act are readily available (Witte 1963; Quadagno 1988). It suffices here to note the roles that researchers played in shaping the measure that originally established federal old-age insurance, and enabled the states to relieve the aged poor, the blind, and dependent and crippled children; to provide maternal and child welfare on public health services; and to administer unemployment compensation laws. Witte's report was a marvel of statecraft and intellectual analysis, melding contributions by scholars and technicians. Only the Federalist Papers surpass its importance as a position paper in the annals of American public policy making.

Witte's blueprint was shaped by a concern for programmatic balance and a commitment to longstanding values and mores. He stressed transgenerational objectivesespecially the need to safeguard families against risks over which they had no controlin a piecemeal, categorical approach to hazards likely to occur at successive stages of the lifecourse. Hence reducing the incidence of old-age improverishment was claimed to benefit younger and middle-aged members of the family unit as well as the elderly. The federal government was accorded unprecedented responsibilities, but not without allowing considerable leeway for administrative discretion at the state level. Similarly, the proposed public initiatives were designed to encourage private innovations and individual opportunities to achieve a measure of economic security.

Given the philosophical tensions and administrative complexities grafted into the act, disagreements over priorities naturally erupted. There are lessons to be learned from the ways researchers handled themselves in the policy arena. The following three, in particular, are worth noting.

1. Debates over Social Security tended to shy away from radical structural changes and to minimize ideological differences. At first glance it seems curious that Abraham Epstein and I.M. Rubinow played such a minor role in crafting the 1935 act. As authors and lobbyists, both men had established reputations as distinguished social insurance advocates long before FDR and his advisors became figures of any national prominence in this area. Ironically their positions were too well known. Both felt that the nation had a responsibility to care for all disadvantaged people regardless of what 
they had contributed to the commonweal. This proposition was deemed too radical for the times; implementing the idea would have necessitated a profound restructuring of societal institutions. That Epstein and Rubinow were unwilling to concede their bottom line made them liabilities to researchers who recognized that principles can be bent for the sake of practical politics without breaking them.

2. Even with the "vital center," intellectual input had to mesh with the issues policymakers wanted to address. Early on, Witte made it clear that he was primarily interested in designing a program of unemployment compensation as the foundation for economic security. Indeed, in a speech drafted for the president in November 1934, he broadly hinted that this might not be the right time for legislation on old-age security. Media reaction was critical, and public outrage immediate: the plight of the aged poor, after all, was manifest. Consequently, ideas about old-age dependency being developed by two members of Witte's staff (J. Douglas Brown, a Princeton economist, and Barbara Nachtrieb Armstrong, a Berkeley law professor who had studied European social insurance schemes) gained greater prominence than might otherwise have been the case. Old-age assistance received top billing in the 1935 act. A provision for assisting states administer their unemployment compensation programs was included in the law, but bolder employment policies would have to wait.

3. For intellectual no less than tactical reasons, social science research had to be in mature enough shape so lawmakers could apply findings in changing present policy. Witte and his staff marshaled data to show that illness was one of the major causes of economic insecurity. He recounted major steps that federal, state, and local governments had already taken in the public health area, and pointed out the inadequacies of commercial and nonprofit sickness insurance. But defining the scope of the health-care problem and developing an approach that complemented the overall social insurance strategy could not be accomplished in the time allotted. Witte was willing to commend a national health insurance program in principle, but he could not recommend a set of legislative proposals until more research was conducted. The 1935 act thus reflected the intellectual honesty of researchers who knew the limitations of their data. By allotting funds so that states could broaden the scope of public health initiatives and vocational rehabilitiation, the groundwork was laid for more ambitious initiatives.

These three tendencies-opting for centrist positions, making sure good ideas fit the moment, and recommending reform through incremental changes-became the intellectual modus operandi for Social Security policy making thereafter.

Congress ensured that research would be an integral element in future deliberations. Under Title VII, a Social Security Board was established which, among other things, had "the duty of studying and making recommendations as to the most effective methods of providing economic security through social insurance" (Pifer and Chisman 1985 , p. 92). This provision, however, did not guarantee a continued dialog among technicians and scholars.

\section{A Widening Gap}

Between 1937 and 1972, research technicians who werc closely identified with the system did most of the conceptual thinking and data analysis necessary for Social 
Security policy making. Administrators successfully recruited for their internal Bureau of Research and Statistics a first-rate cadre of professionals with graduate training in economics, statistics, and other social sciences. Many were women unable to obtain sufficiently challenging academic posts. Some, like Ida Merriam, Alfred Skolnik, and Lenore Epstein Bixby, spent their entire careers in the bureau compiling statistics, evaluating the impact of current Social Security programs on various recipient populations, and studying problems concerning legislative and administrative matters in federal-state relations. In at least one instance, a Social Security researcher's analysis became the basis for broader policy innovation: Mollie Orshansky's index of need was the prototype for the poverty line used in the War on Poverty during the $1960 \mathrm{~s}$.

Typically, the technicians published their work-in-progress in the Social Security Bulletin, which remains the most reliable source of data and information about the program. They also did the bulk of the staff work for the six advisory councils convened during the first 35 years of the system's history. The factual materials contained in the reports of these bodics provided the justification necessary for extending coverage and periodically increasing old-age insurance benefits, enacting Disability Insurance (1956) and Medicare (1964) and establishing a nationwide income floor through the Supplemental Security Income Program (1972).

Efforts were also made to entice scholars based in universities to do research on Social Security. Along with labor representatives, business executives, welfare and health-care professionals, and government officials, academics were regularly appointed to serve on advisory boards. When Wilbur Cohen left government during the Eisenhower administration, he collaborated with economists, political scientists, and social welfare experts at the University of Michigan in using federal census records and survey data to measure the extent of poverty at various stages of life. Some of Social Security's founding fathers-Edwin Witte, J. Douglas Brown, Arthur Altmeyer, and Charles I. Schottland-published insiders' accounts of the early years, stressing the need for future research on philosophical and macroeconomic matters (Berkowitz 1987). In the 1960s the Social Security Administration began making funds available to enable graduate students to write dissertations using its data.

Yet few scholars evinced much interest in Social Security, especially prior to the 1960s. Symposia held at Princeton, Berkeley, Brandeis, Michigan, and Wisconsin generated spurts of interest. Eveline Burns, a professor of social work at Columbia who had attacked some of the original provisions, broadened her criticisms (1949). Paul Samuelson (1967) wondered whether Social Security was a Ponzi game, and Milton Friedman regularly contested its place in a capitalist society. Most of the significant scholarly research on Social Security at the time was being done in think tanks, however, not universities. The Twentieth Century Fund, which had issued two studies in 1937, commissioned John Corson and John McConnell to analyze The Economic Needs of Older People (1956). Similarly, leaders at The Brookings Institution recognized that administering Social Security was more than a routine operation like delivering the mail; an analysis by staff members Pechman, Aaron, and Taussig (1968) demonstrated the importance of taking a broad perspective in contemplating reform. But these are the notable exceptions.

The scholar's relative lack of interest is understandable. Doing research in Social Security required considerable technical background. Before investing the time and 
energy to learn program particulars, scholars needed to see the payoff. But it was not clear that studying Social Security as a "problem" would count for much in academic circles. Despite some people's ideological objections and continual controversies over financing, the program appeared basically solid in the capable hands of its technical experts and high-level advocates. As a consequence, scholars and technicians rarely addressed the same Social Security issues. When they did, they adopted different paradigms and wrote for different audiences.

Paradoxically, as a financial "crisis" began to swirl around Social Security, and as the institution's image became less stolid, the system became more interesting to the scholars. Conservatives focused on the vast sums of dollars involved and the overwhelming proportion of workers potentially and retirees presently eligible for benefits. They challenged Social Security's redistributive features, arguing that to meet the needs of an aging population under the current rules would bankrupt the country (Buchanan 1975). Political scientists, sociologists, and economists increasingly invoked neoMarxist theories to get a handle on the political cconomy. Some hypothesized that Social Security's problems were at once symptoms and products of a more deeply rooted "crisis of legitimacy" (Myles 1984). Philosophers, meanwhile, grappled with the intended purposes of "entitlements" under Social Security as part of a broader effort to explicate the meanings of "justice," "equity," and "rights" (Cole and Gadow 1986).

The immediate effect of this spate of scholarly articles and monographs on social science research was mixed. On the one hand, it provided an opportunity for fruitful debate between scholars and technicians. Economists at the Social Security Administration, for instance, challenged Harvard economist Martin Feldstein's hypotheses concerning the effects of Social Security on private savings and national capital accumulation. They were so successful in questioning some of his underlying assumptions and econometric procedures that Feldstein subsequently qualified his argument (Lesnoy and Homber 1975; Feldstein 1977). On the other hand, the dialog did not reduce discomfort over divergent intellectual styles and purposes. Martha Derthick's Policymaking in Social Security (1979) won the American Political Science Association's most coveted prize, but Social Security officials who had participated in frays with the legislative and executive branches were quick to point out what they considered to be egregious errors in her facts and interpretation. And while no one seriously expected Congress to adopt a radical solution to the Social Security's financial woes, the ad-hoc tinkering advocated by the technicians seemed to most scholars like palliatives that did not face up to tough issues.

Some rapproachement between the two camps took place when lawmakers acknowledged that they needed to "solve" the mess. Jimmy Carter had four blueribbon panels study Social Security problems and recommend reforms. Ronald Reagan's National Commission on Social Security Reform finally pieced together a consensus package that served as the basis for the 1983 amendments. Technicians and scholars worked closely together, drafting policy options and cost-benefit analyses. Reviewing their memoranda indicates that both groups took the status quo as given (thus eschewing radical alternatives), opted for an incremental approach to reform, and freely drew upon ideas from one another (Achenbaum 1986). As had been the case in the $1930 \mathrm{~s}$, the political climate demanded fresh perspectives that could be integrated into ongoing operations, from a variety of quarters. 


\section{Developing Methods to Bridge Gaps}

Since the passage of the 1983 amendments, there has been an uneasy quiet about Social Security. The system survives and in many ways thrives. But it is not clear that its long-term solvency is assured. What to do about the growing Trust Fund surpluses looms as a political issue. And as the articles below indicate, there is still much research to do concerning public opinion and popular confidence, gender issues, disability matters, and larger questions about the political economy. Scholars and technicians must collaborate in new ways, for only a multidisciplinary approach can describe and explain how microlevel adjustments in program rules can have such an impact on people's lives, and a ripple effect on other societal institutions.

To ensure a critical mass of Social Security experts, Congress established the National Academy of Social Insurance in 1986. Like members of the National Academy of Science, these researchers are expected to work together as they lend their talents and credibility in shaping new policies. Significantly, the first round of members selected were nicely balanced between scholars and technicians who had strong publications and broad concerns. In a complementary way, by publishing these essays, the Journal of Aging Studies also hopes to encourage better social science research on Social Security. In style and execution-avoiding ideological bombast, focusing on timely issues, and precisely describing strengths and limitations in data-each article resonates with methods already effectively employed by scholars and technicians. Three other analytic strategies are adopted here that should appeal to readers of this journal:

First, the authors use research as a wedge to differentiate between Social Security myths and realities. Melissa Hardy engages in historical analysis and borrows from the literary deconstructionists to explain the persistence of myths about the economics of aging. Erroneous notions that all older Americans are living well or that the poor elderly deserve no better, she hypothesizes, may be built into our policy fabric itself. Fay Lomax Cook and Edith J. Barrett challenge the prevailing notion that Americans, especially younger ones, evince little confidence on the Social Security program. They find few differences in supportiveness across age groups. Nancy Wolff questions an assumption, set forth in blue-ribbon panels and in the academic press, concerning the uneven impact of Social Security on women. If a systemic bias exists, she shows, it should be a men's issue, for treatment inequities are more appreciable among male subgroups. While acknowledging that strains in the trade-off between efficiency and welfare under Social Security have macroeconomic implications, John Myles cautions researchers not to bend their antipathy into a canard. Far from being a drag on the economy, the growth of centralized, state-administered programs has enhanced general security and, thereby, economic development.

The last two articles focus on the Disability Insurance (DI) program. Most people presume that eligibility criteria are based on some correlation between state of health as it relates to work ability. Henry Brehm and Thomas Vale find, however, that withdrawal from the labor force is more likely to be based on age in combination with any level of impairment. Gender is a modifying factor in this behavior. Tod Porter rejects the notion that fluctuations in DI are due mainly to worsening employment conditions, because changes in the age composition of the insured and in the rate of awards account for declines in the early 1980 s-a period of high unemployment. 
Note how effectively the myth-and-reality device works in articles focusing on very different issues and utilizing dissimilar data. The approach invites the reader onto familiar ground-scholars advance truth by pointing out previous researchers' errors and stereotypes; the education program created by the Social Security Administration depends on technicians to provide hard evidence to dispel myths about the program. Hence, a natural bridge between the two camps is created.

Second, none of these articles are addressed to a disciplinary audience alone. Each adopts a comparative approach, which lends itself to cross-disciplinary analysis. For instance, Wolff interprets the latest demographic and economic data concerning gender differences generated by Social Security scholars and technicians. What makes her article exciting, however, is the legal perspective she introduces. Wolff shows that different notions of property rights, especially in marriage, alter many of the distributional equity generalizations found in the literature. Brehm and Vale demonstrate the value of using data for purposes not originally intended. By massaging the Framingham Heart Study so that its data were compatible with disability categories established by Social Security analysts, they were able to test an impairment criterion on a larger population than just DI recipients. This enabled them to distinguish between "impairment" and "disability" in ways that technicians never tried. Similarly, Myles' article illustrates the power of secondary analysis done with an eye to the big picture. He teases generalizations about Social Security out of studies across place (Canada, Great Britain, and the United States) and discipline (philosophy, economics, and political science). Because Myles has a feel for historical process, he is able to show how values, structures, and policies interact over time.

A developmental approach, in fact, is the third strategy adopted here. Hardy examines how ideas change over time so that she can apply lessons from the past. The elderly's particular "burden of dependency," she claims, is an ageist artifact - the historical consequence of their earned rights to welfare benefits under various titles of the Social Security System. Policymakers thus will have to rethink the line between unemployment and retirement and issues of distributive justice. Cook and Lomax apply a developmental approach comparing the cross-sectional survey from earlier polls to their own recent telephone survey. They are quite sensitive to cohort differences and shifting circumstances over time. The pair end their article by raising the possibility that new stresses on public support for the elderly through Social Security will occur, if the media exaggerates the extent of affluence among the aged. Porter is also concerned with placing his data on a reliable time line. In addition, he links the Disability Insurance program to the Black Lung program, unemployment policies, and other Social Security entitlements to show interactive effects. This tack enables him to forecast that raising the retirement age (as stipulated by the 1983 amendments) will not necessarily save the system as much as anticipated because the number of DI beneficiaries would grow concurrently.

These six articles indicate that there is a place for social scientists interested in aging research among Social Security scholars and technicians. Gerontologists know how to play the myth-and-reality game well. The field has been built by researchers who are masters at cross-disciplinary discourse and analysis. Specialists in aging are accustomed to comparing normative continuities and disparate changes in phenomena concurrently (Achenbaum 1987). Transferring skills to a new knowledge area entails minimal costs. 
Studying Social Security as an aging institution may have real payoffs for gerontology. The organization is dynamic and it interacts with a variety of other large systems. Learning the details necessary to understand Social Security's growth and its function in the political economy will force experts in aging to delve into materials by both scholars and technicians. That exercise should underscore a fact that every gerontologist knows: how difficult but how necessary it is to fit "parts" into an aging "whole" and to acknowledge that many pieces of the puzzle do not yet (and may not ever) fit. Further, Social Security here and abroad has matured contemporaneously but in different ways than is the case of the succession of cohorts it has affected. Looking at longer-lived individuals in an aging society through the Social Security institutional prism could give gerontologists new perspectives on the (dis)connections among age, aging, and aged at various levels of analysis.

\section{REFERENCES}

Achenbaum, W.A. 1986. Social Security: Visions and Revisions. New York: Cambridge University Press.

1987. “Can Gerontolugy Be a Science?” Journal of Aging Studies, 1: 3-18.

Berkowitz, E.D. (ed.). 1987. Social Security after Fifty. Westport, CT: Greenwood Press.

Buchanan, J.M. 1975. "Public Finance and Public Choice." National Tax Journal, 28: 383-394.

Burns, E.M. 1949. The American Social Security System. Boston, MA: Houghton Mifflin.

Cole, T.R., and S. Gadow (eds.). 1986. What Does It Mean to Grow Old? Durham, IN: Duke University Press.

Corson, J.J., and J.W. McConnell. 1956. The Economic Needs of Older People. New York: The Twentieth Century Fund.

Derthick, M. 1979. Policymaking for Social Security. Washington, DC: The Brookings Institution. Feldstein, M. 1977. "Does the United States Save Too Little?" American Economic Review, 67: $116-121$.

Haskell, T.L. (ed.) 1984. The Authority of Experts. Bloomington: Indiana University Press.

Lesnoy, S.D., and J.C. Hambor. 1975. "Social Security, Saving, and Capital Formation." Social Security Bulletin, 38: 3-15.

Lynd, R.S. 1939. Knowledge for What? Princeton, NJ: Princeton University Press.

Myles, J. 1984. Old Age in the Welfare State. Boston, MA: Little, Brown.

Oleson, A., and J. Voss (ed.). 1979. The Organization of Knowledge in Modern America, 1860-1920. Baltimore: The Johns Hopkins University Press.

Pechman, J.A., H.J. Aaron, and M.K. Taussig. 1968. Social Security: Perspectives for Reform. Washington, DC: The Brookings Institution.

Pifer, A., and F. Chisman (eds.). 1985. The Report of the Committee on Economic Security of 1935. Washington, DC: National Conference on Social Welfare.

Quadagno, J.S. 1988. The Transformation of Old Age Security. Chicago: University of Chicago Press.

Samuelson, P. 1967. "Paul Samuelson on Social Security." Newsweek 57: 88.

Witte, E.E. 1963. The Development of Social Security Act. Madison: University of Wisconsin Press. 